Research.

\title{
THE EFFECT OF RENTABILITY RATIO, SOLVABILITY RATIO, LIQUIDITY RATIO UPON THE COMPANY'S VALUE (EMPERICAL STUDY OF MINING COMPANIES SUB SECTOR OF METAL AND OTHER MINERAL REGISTERED IN THE INDONESIA STOCK EXCHANGE IN 2012 - 2016)
}

\author{
Gilang Ramadhan Fajri \\ Politeknik BBC, Sukabumi, Indonesia
}

Received: January 23, 2018; Accepted: April 9, 2018; Published: June 30, 2018

To cite this article: Gilang Ramadhan Fajri, The Effect of Rentability Ratio, Solvability Ratio, Liquidity Ratio upon the Company's Value (Emperical Study of Mining companies Sub Sector of Metal and Other Mineral Registered in The Indonesia Stock Exchange in 2012 - 2016), The Accounting Journal of BINANIAGA, Vol. 03, No. 01, June 2018, pp. 39 - 50.

Abstract. This research is an empiric study to examine The Effect of Rentability Ratio, Solvability Ratio, Liquidity Ratio upon the Company's Value (Empiric Study of the Mining Company, Sub Sector Metal and other Mineral registered in the Indonesia Stock Exchange in 2012 - 2016) and sampling technique has applied purposive sampling which are 7 of 9 companies registered in the Indonesia Stock Exchange. The objective of this research is to prove the Effect of Solvability ratio, Liquidity ratio and Rentability ratio upon the Company's value measured by Price Book Value $(P B V)$ and which variables have been more dominantly affecting Price Book Value (PBV) The analysis techniques which have been used in this research are classical assumption, multiple linear regression and hypothesis test using $t$-statistic to examine partial regression coefficient and f-statistic to examine the reliability of the research model using level of significance of $10 \%$. Moreover, the examination of classical assumption test has been covering normality test, multicolinierity test, heteroscedasticity test and autocorrelation test, the effect of independent variable upon dependent variable refers to the company's book value (PBV) which is only 0.17 or equals to $17 \%$. However the remaining value of 0.83 or equals to $83 \%$ has been described by other variables which are not included in this research and the result of the research of the variables being used for the period of variable debt to assets (DAR) which has been most dominantly affecting the company's value of 0.627 or $62.7 \%$.

Keywords : Gross Profit Margin (GPM), Return On Equity (ROE), Debt to Equity Ratio (DER), Debt to Asset Ratio (DAR), Current Ratio, Price Book Value (PBV).

\section{INTRODUCTION}

\section{A. Background of the Research}

There are so many factors affecting the Company's Value, the first factor that has been affecting the company's value is Rentability ratio. Rentability is the ability of a company to get more earnings during a certain period. On the other word, Rentability of a company has indicated the comparison between earnings and assets or capital that can obtain the related earnings. Earnings has reflected the capability of the company achieving a lot of earnings for the shareholders, the higher

Gilang Ramadhan Fajri: The Effect of Rentability Ratio, Solvability Ratio, Liquidity Ratio upon the Company's Value (Emperical Study of Mining companies Sub Sector of Metal and Other Mineral Registered in The Indonesia Stock Exchange in 2012 - 2016) 
the rentability ratio, the higher returned of investment will be for the shareholders and better job performance of the company will increase the company's value.

Second factor which is affecting the company's value is ratio solvability, solvability is a ratio indicating the amount of the assets of company funded by its liabilities. It means that how big amount of the liabilities of the company comparing with its assets. This ratio is a measurement indicating the ability of the company to pay all its debts. One of the important factors in financing is debt or leverage.

The Third factor which is affecting the company's value is liquidity ratio. Liquidity is a ratio measuring the ability of the company to pay its short-term liabilities. This ratio can be calculated by the information resource about the working capital which is the accounts of current assets and current liabilities. Therefore, liquidity ratio has been affecting the financial performance of the company reflecting on the ratio which is related to the value of company's shares.

From those three factors, the researcher has applied some variables of the research to measure the financial ratio which is Gross Profit Margin (GPM) and Return On Equity to represent Rentability ratio, Debt to Equity Ratio (DER) and Debt to Asset Ratio (DAR) ro represent solvability ratio and current ratio representing liquidity ratio, however, value of the company has been measured by the variable of Price Book Value (PBV), the reason why the researcher has chosen that kind of variable is as follows; the first reason, it is quite easy to understand and is very often being used to measure the job performance of a company; the second reason, finance ratio being used is more simple replacement than information provided in the financial reporting and the third reason, Price Book Value has been chosen as dependent variable since PBV is the comparison between market price and share booked value, since book value per share has indicated net assets owned by the stakeholders which is by having one piece of share, its price book value (PBV) is increased and market price of its share is becoming more expensive.

\section{B. Problems Identification} follows;

Based on the description above, problems identification of this research are as

1. Investors hould have to be more carefully to study the information related to the financial performance of the company. This kind of information is the information coming from legal report of stock exchange authority or Stock Market Surveillance Institution published in the Financial Report, ICMD, Annual Report.

2. The information of the financial performance reporting which is especially related to the ratios of Rentability, Solvability and Liquidity which furthermore could be used as references and study of economical decision making by either investors or internal party of the company.

\section{Problems Limitation}

Scope of this research has covered economics and accountancy science, specifically which are describing Stock Market. The limitation of this research is as the following;

1. This research has been limited only using 7 of 9 mining companies sub sector of metal and other minerals registered in the Indonesia Stock Exchange for the last 5 years period of $2012-2016$.

2. The variables being studied has been covering the independent variables of Gross Profit Margin (GPM). Return On Equity (ROE), Debt to Equity Ratio (DER), Debt to Asset Ratio (DAR), Current ratio and dependent variable which is Price Book Value (PBV). 


\section{Problems Design of The Research}

1. Is there any significant effect partially between the variable of GPM, ROE, DER, DAR and Current ratio upon the company's value measured by PBV?

2. Is there any significant effect simultaneously between variables GPM, ROE, DER, DAR and Current ratio upon the company's value measured by PBV?

3. Which are the most dominant variables affecting the company's value measured by PBV?

\section{E. The Objectives and Benefit of The Research}

\section{The Objective of the Research}

a. Analyzing how big effects of GPM, ROE, DER, DAR and Current ratio variables has happened upon the value of company measured by PBV.

b. Getting an empiric evidence about the effect of variables GPM, ROE, DER, DAR and Current ratio either partially or simultaneously upon the company's value measured by PBV

c. Studying which variable has dominantly affected the company's value measured by PBV?

2. Benefit of the Research

a. Theoretical Benefit

This research is expected to be used as an input or additional knowledge and as an empirical evidence about the effect of financial ratios as the indicators upon the Price Book Value (PBV) of mining company subsector metal and other mineral in Indonesia, and it could be used as the reference of the researcher who is going to perform furthermore the similar research.

b. Practical benefit

For the purpose of mining sectors, they can use this research as the standard of financial decision making to improve the company's job performance which could elevate the value of company obviously.

c. Academics Benefit

Academically, this research is expected to be able to contritube literary the literatures in Accountancy and Finance subject.

\section{LITERATURES REVIEW}

\section{A. Pecking Order Theory}

Referring to Myers (2001), pecking order theory is defined that "A company having high probability but it has had low liabilities since the company is having a huge amount of internal fundings resources." Pecking Order Theory does not have any optimal capital structure. Specifically the company has hierarchically had preferences using its finance. Pecking order theory has explained why the company is having hierarchical preference choosing financial resources. Profitable company usually has asked less amount of the debt since they have required only small amount of external financial support. Less profitable companies have had bigger amount of the debts since their internal financial support is not sufficient to cover all their needs, however having debts from external source is more convenient for them. They prefer external fundings better as a debt rather than their internal capital

Gilang Ramadhan Fajri: The Effect of Rentability Ratio, Solvability Ratio, Liquidity Ratio upon the Company's Value (Emperical Study of Mining companies Sub Sector of Metal and Other Mineral Registered in The Indonesia Stock Exchange in 2012 - 2016) 
because of the consideration of long term debt payment issue is cheaper than the share expenses issue.

\section{B. The Company's Value}

The value of a company is related to the perception of an investor which is quite often referred to the price of the shares, however, according to Rinnaya et al. (2016) the value of a company is a certain condition being achieved by a company as the reflection of public trustworthy upon the related company after having been through the process of its activities for years which has started from the establishment of the company up to now. The increasing of the company's value is an achievement getting along with the owner interest which has increased also the prosperity of the owner. Had the company been running well, the value of its shares would increase accordingly and its shares value could be a proper index to measure the effectivity of a company.

\section{Ratio Rentability}

1. Gross Profit Margin

Gross Profit Magin is a ratio being used to measure the percentage of gross profit over net sales. This ratio is calculated by dividing gross profit with net sales.

2. Return On Equity

Return On Equity is a ratio indicating the amount of equity contribution to create net profit. Nevertheless this ratio is being applied to measure the amount of net profit expected from each rupiah invested in the total of the equity.

\section{Solvability Ratio}

1. Debt to Equity Ratio

Debt to Equity Ratio is describing how far the capital owner is able to pay all the liabilities from external party and it is the ratio measuring how far the company has been financed by the debts. This kind of ratio is named leverage ratio. Leverage ratio is the ratio measuring how good the structure of company's investment is. The investment structure is permanent financing support consisting of long-term liabilities, preference share and capital of the shareholders (Wahyono, 2002:12)

\section{Debt to Asset Ratio}

Debt to Asset Ratio is a comparison ratio between total liabilities and total assets. However, this ratio has been indicating how far the liabilities could be paid by the assets. Referring to Sawir (2008:13) debt ratio is the ratio indicating the proportion between current liabilities and current assets.

\section{E. Liquidity Ratio}

Low current ratio is usually identifying the problems of liquidity, as a matter of fact, current ratio which is quite high is not quite good since it is indicating that passive assets will decrease the company's profitability (Sawir, 2009:10). If liquidity level has been using current ratio as its measurement tool, liquidity level or current ratio of the company could be increased by the following efforts(Riyanto, 2008):

1. Using certain current liabilities which is expected to increase current assets.

2. Using certain current assets which is expected to reduce the amount of current liabilities.

3. Reducing the amount of current liabilities simultaneously by decreasing also the current assets.

Gilang Ramadhan Fajri: The Effect of Rentability Ratio, Solvability Ratio, Liquidity Ratio upon the Company's Value (Emperical Study of Mining companies Sub Sector of Metal and Other Mineral 


\section{THE RESEARCH METHODOLOGY}

\section{A. Type of The Research}

In this research, the researcher has applied causal research in order to test the hypothesis about the effect of five independent variables upon one dependent variable.

\section{B. The Definition and Operational Variable}

1. Dependent variable

Dependent variable is the variable which is affected or is caused by independent variable

2. Independent variable

Independent variable is the variable affecting or causing any changes of dependent variable.

\section{Variable Measurement}

Variable is something being used as a distinctive feature, character or size owned or discovered by the research regarding a particular concept. Measuring variable is the process of determining the total or intensity of information about people, event, idea, and or particular object which is related to the correlation with the problems or business opportunity. On the other word, using the measurement process is determining the figures or table upon the characteristics or attributes of an object, or each kind of phenomena or event that is applying specific rules which have been indicating the total and or the quality of some factors being studied.

\section{Population and Samples of The Research}

Population is a generalized area consisting of an object or subject having quality and specific characteristics defined by the researcher to be studied and furthermore it has to be concluded (Sugiyono, 2010). However, The Sample of the Research according to (Margono, $2004: 121)$ is defined that sample of a research has appeared due to the following:

1. The researcher has intended to reduce the research objects since the population are quite huge so that only a part of them is going to be studied.

2. This research has intended to provide a generalization of the result of the research, it means that the conclusions upon the object, symptoms, or event will be made as widespread as possible.

\section{E. Sample Criteria}

Criteria which is to be considered in the sampling collection of this research are as follows:

1. Publishing complete yearly financial report years of $2012-2016$

2. Having the data of Rentability ratio, Solvability ratio and Liquidity ratio during the observation period upon the yearly financial report of a company.

3. Having the value of variables being studied within the research period of time.

\section{F. Data Collection Method}

\section{Classical Assumption Test}

The objective of classical assumption test is providing a definite meaning which is regression equation produced is having an exact estimation, not bias and consistent.

Gilang Ramadhan Fajri: The Effect of Rentability Ratio, Solvability Ratio, Liquidity Ratio upon the Company's Value (Emperical Study of Mining companies Sub Sector of Metal and Other Mineral Registered in The Indonesia Stock Exchange in 2012 - 2016) 


\section{Multiple Regression Analysis}

Analysis of multiple linear regression is a linear correlation between two or more independent variables and dependent variable. This analysis is figuring out the correlation between independent variable and dependent variable whether each independent variable is correlated positively or negatively.

\section{THE RESULT OF ANALYSIS AND THE DESCRIPTION}

\section{A. Descriptive Analysis}

Descriptive Statistics

\begin{tabular}{|l|r|r|r|r|r|}
\hline & $\mathrm{N}$ & Minimum & Maximum & Mean & Std. Deviation \\
\hline GPM & 35 & -2.4025 & .5779 & .105109 & .4835320 \\
\hline ROE & 35 & -.2767 & .3273 & .002420 & .1452960 \\
\hline DER & 35 & .01 & 2.11 & .7066 & .55865 \\
\hline DAR & 35 & .01 & 54.00 & 1.8820 & 9.07078 \\
\hline Current Ratio & 35 & .2928 & 78.0041 & 6.085197 & 13.8157083 \\
\hline PBV & 35 & .27 & 4.11 & 1.4586 & .93896 \\
\hline Valid N (listwise) & 35 & & & & \\
\hline
\end{tabular}

1. Mean Value (GPM) of the 35 samples is 0.105 or $10.5 \%$ which is lower than the value of standard deviation of 0.483 , it means that metal and other mineral companies have gained gross profit of 0.105 times from net sales $(0.105: 1)$ or in other word, each Rp 1 of net sales has obtained gross profit of $\mathrm{Rp} 0.105$.

2. Mean value (ROE) of the 35 samples is 0.002 or $0.2 \%$ which is lower than the value of standard deviation of 0.145 explaining that the metal and other mineral companies have gained nett profit of 0.002 times from the equities $(0.002: 1)$ or it can say that each $\mathrm{Rp} 1$ of equity has gained net profit of $\mathrm{Rp}$ 0.002 .

3. Mean value (DER) of the 35 samples is 0.706 or $70.6 \%$ which is higher than the value of standard deviation of 0.558 , it means that metal and other mineral companies on average is having total liabilities of 0.706 times from the equity of shareholders $(0.760: 1)$ or in other word, every $R p 1$ of the equity of shareholder has guaranteed $\mathrm{Rp} 0.706$ of total liabilities.

4. Mean value (DAR) of the 35 samples is 1.88 or $188 \%$ which is lower than the value of standard deviation of 9.07 , it means that metal or other mineral companies on average is having the total liabilities of 1.88 times from the total assets $(1.88: 1)$ or in other word, every $R p 1$ of total assets on average has guaranteed $\mathrm{Rp} 1.88$ of total liabilities.

5. Mean value (Current Ratio) of the 35 samples is $6.08 \mathrm{pr} 608 \%$ which is lower than the value of standard deviation of 13.8, it means that metal and other mineral companies on average is having current assets of 6.08 times from current liabilities $(6.08: 1)$ or in other word, every Rp 1 of current liabilities on average has guaranteed $\mathrm{Rp} 6.08$ current assets.

6. Mean value (PBV) of 35 samples is $1.45 \%$ or $145 \%$ which is higher than the value of standard deviation of 0.938 which means that metal and other mineral companies on average is having share market value of 1.45 times from share booked value per share $(1.45: 1)$ or in other word, every Rp 1 of share booked value on average has gained $\mathrm{Rp} 1.45$ of share market value.

Gilang Ramadhan Fajri: The Effect of Rentability Ratio, Solvability Ratio, Liquidity Ratio upon the Company's Value (Emperical Study of Mining companies Sub Sector of Metal and Other Mineral 


\section{B. Classical Assumption Test}

\section{Normality Test}

One-Sample Kolmogorov-Smirnov Test

\begin{tabular}{|c|c|c|}
\hline & & $\begin{array}{l}\text { Unstandardized } \\
\text { Residual }\end{array}$ \\
\hline $\mathrm{N}$ & & 35 \\
\hline \multirow{2}{*}{ Normal Parameters ${ }^{\mathrm{a}, \mathrm{b}}$} & Mean & .0000000 \\
\hline & Std. Deviation & .79006447 \\
\hline \multirow[t]{3}{*}{ Most Extreme Differences } & Absolute & .124 \\
\hline & Positive & .124 \\
\hline & Negative & -.093 \\
\hline Test Statistic & & .124 \\
\hline Asymp. Sig. (2-tailed) & & $.193^{c}$ \\
\hline
\end{tabular}

Referred to the output above, significance value (Asymp.Sig 2-tailed) is 0.193 since the significance value is more than $0.05(0.193>0.05)$ of residual value distributed normal.

\section{Multicolinearity Test}

Coefficients $^{a}$

\begin{tabular}{|c|c|c|c|c|c|c|c|c|}
\hline & \multirow[b]{2}{*}{ Model } & \multicolumn{2}{|c|}{$\begin{array}{l}\text { Unstandardized } \\
\text { Coefficients }\end{array}$} & \multirow{2}{*}{\begin{tabular}{|c|}
$\begin{array}{c}\text { Standardized } \\
\text { Coefficients }\end{array}$ \\
Beta \\
\end{tabular}} & \multirow[b]{2}{*}{$\mathrm{t}$} & \multirow[b]{2}{*}{ Sig. } & \multicolumn{2}{|c|}{ Collinearity Statistics } \\
\hline & & $B$ & Std. Error & & & & Tolerance & VIF \\
\hline 1 & (Constant) & 1.081 & .289 & & 3.741 & .001 & .642 & \\
\hline & GPM & -.375 & .379 & -.193 & -.989 & .331 & .645 & 1.557 \\
\hline & ROE & -1.780 & 1.257 & -.276 & -1.416 & .167 & .696 & 1.550 \\
\hline & DER & .629 & .315 & .374 & 1.999 & .055 & .831 & 1.437 \\
\hline & DAR & .009 & .018 & .084 & .491 & .627 & .796 & 1.203 \\
\hline & Current Ratio & -.007 & .012 & -.098 & -.557 & .582 & .642 & 1.256 \\
\hline
\end{tabular}

Referred to the output above, tolerance value of all the variables above is higher than 0.05 and variance inflation factor value (VIF) of all variables is less than 10 . It is concluded that not any multicoliniearity has happened among independent variables. However, the five variables can be used to predict the value of return on equity (ROE) during the observation period of time.

3. Heteroscedastic Test

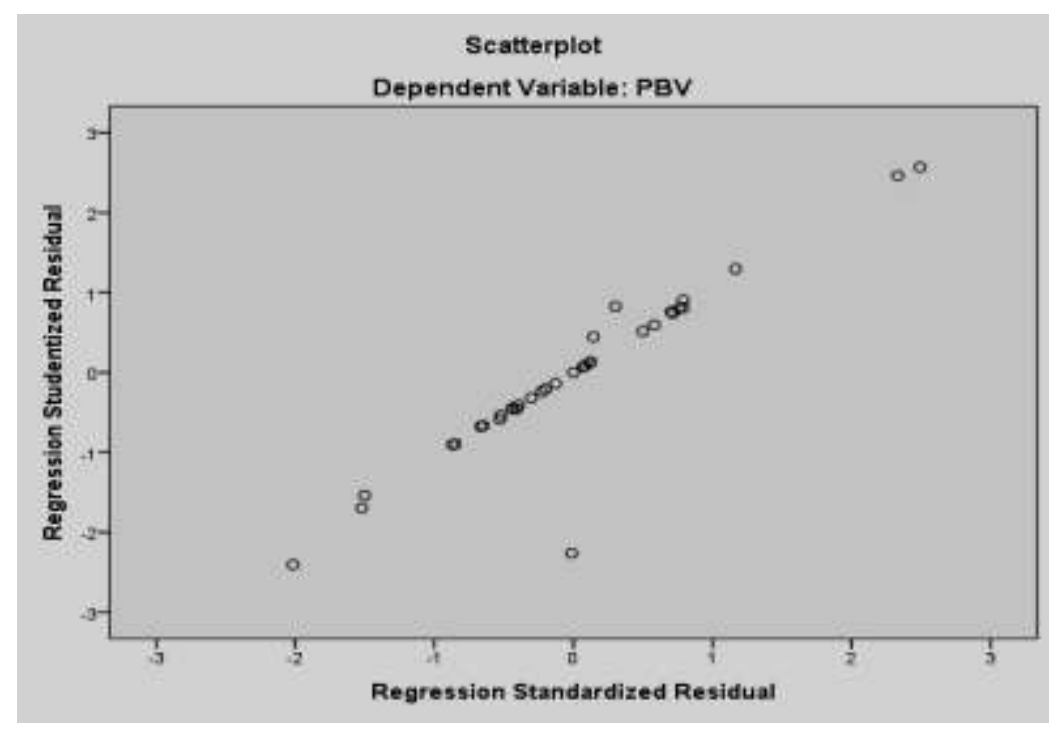

Gilang Ramadhan Fajri: The Effect of Rentability Ratio, Solvability Ratio, Liquidity Ratio upon the Company's Value (Emperical Study of Mining companies Sub Sector of Metal and Other Mineral Registered in The Indonesia Stock Exchange in 2012 - 2016) 
Referred to the output above it can figure out that scatterplots did not shape a clear pattern, and it is scaterring above and under 0 point on $\mathrm{Y}$. So that, it can be concluded that there is not any problems of heteroscedasticity happned on the regression model.

\section{Autocorrelation Test}

Detecting autocorrelation using Durbin Watson value with the

a. If the figures of $D-W$ is below -2 , a positive autocorrelation has happened.

b. If the figures of $D-W$ is between -2 and +2 , autocorrelation has not happened.

c. If the figures of $\mathrm{D}-\mathrm{W}$ is over +2 , negative autocorrelation has happened.

Model Summary ${ }^{\mathrm{b}}$

\begin{tabular}{|c|c|r|r|r|r|}
\hline Model & $\mathrm{R}$ & $\mathrm{R}$ Square & $\begin{array}{c}\text { Adjusted R } \\
\text { Square }\end{array}$ & $\begin{array}{c}\text { Std. Error of } \\
\text { the Estimate }\end{array}$ & Durbin-Watson \\
\hline 1 & $.540^{\mathrm{a}}$ & .292 & .170 & .85547 & .948 \\
\hline
\end{tabular}

The value of $D-W=09.48$ is still between -2 and +2 , it means that there is not any autocorrelation happened.

\section{HYPOTHESIS TEST USING MULTIPLE REGRESSION}

\section{A. Multiple Linear Analysis}

\begin{tabular}{|c|c|c|c|c|c|c|}
\hline \multicolumn{7}{|c|}{ Coefficients $^{a}$} \\
\hline & \multirow{2}{*}{ Model } & \multicolumn{2}{|c|}{ Unstandardized Coefficients } & $\begin{array}{c}\text { Standardized } \\
\text { Coefficients }\end{array}$ & \multirow[t]{2}{*}{$t$} & \multirow{2}{*}{ Sig. } \\
\hline & & $B$ & Std. Error & Beta & & \\
\hline \multirow[t]{6}{*}{1} & (Constant) & 1.081 & .289 & & 3.741 & .001 \\
\hline & GPM & -.375 & .379 & -.193 & -.989 & .331 \\
\hline & ROE & -1.780 & 1.257 & -.276 & -1.416 & .167 \\
\hline & DER & .629 & .315 & .374 & 1.999 & .055 \\
\hline & DAR & .009 & .018 & .084 & .491 & .627 \\
\hline & Current Ratio & -.007 & .012 & -.098 & -.557 & .582 \\
\hline
\end{tabular}

t-test result using SPSS 22 program has obtained the following result:

$Y=1.081-0.375 X_{1}-1.780 X_{2}+0.629 X_{3}+0.009 X_{4}-0.007 X_{5}$

interpreting the regression above as follows:

\section{B. Constanta (a)}

Refers to the regression equation above, the constanta of 1.081 means that there is not any change of the variable GPM, ROE, DER, DAR and Current Ratio has happened before, then the value of PBV is 1.081 .

C. GPM $\left(X_{1}\right)$ upon PBV $(Y)$

GPM coefficient value of variable $X_{1}$ is 0.375 and negative, it is indicating that GPM is having an inverted correlation with PBV. It has explained that each 1 point of GPM increasing, then variable PBV $(\mathrm{Y})$ will decrease 0.375 with the assumption that the other independent variables of regression model are constant.

\section{ROE $\left(\mathrm{X}_{2}\right)$ upon PBV $(\mathrm{Y})$}

ROE coefficient value of variable $X_{2}$ is 1.780 and negative, it has indicated that ROE is having inverted correlation with PBV. It has explained that each 1 point of

Gilang Ramadhan Fajri: The Effect of Rentability Ratio, Solvability Ratio, Liquidity Ratio upon the Company's Value (Emperical Study of Mining companies Sub Sector of Metal and Other Mineral 
ROE increasing, then PBV $(Y)$ variable will decrease 1.780 with the assumption that other independent variables of regression model are constant.

\section{E. $\operatorname{DER}\left(\mathrm{X}_{3}\right)$ upon PBV $(\mathrm{Y})$}

DER coefficient value of variable $X_{3}$ is 0.629 . It means that every 1 point of DER increasing then PBV $(Y)$ variable will increase 0.629 with the assumption that other independent variable of regression model are constant.

\section{F. DAR $\left(\mathrm{X}_{4}\right)$ upon PBV $(\mathrm{Y})$}

DAR coefficient value of variable $X_{4}$ is 0.009 . It means that every 1 point of DAR increasing, then PBV $(Y)$ variable will increase 0.009 with the assumption that other independent variables of regression model are constant.

\section{G. Current Ratio ( $\left.\mathrm{X}_{5}\right)$ upon PBV (Y)}

Current ratio coefficient value of variable $X_{5}$ is 0.007 and negative, it has indicated that Current Ratio has had an inverted correlation with PBV. It means that each 1 point of Current ratio increasing, then PBV $(Y)$ variable will decrease 0.007 with the assumption that other independent variables of regression model are constant.

\section{H. Partial Hypothesis Test (t-test)}

\begin{tabular}{|c|c|c|c|c|c|c|}
\hline \multicolumn{7}{|c|}{ Coefficients $^{a}$} \\
\hline & \multirow{2}{*}{ Model } & \multicolumn{2}{|c|}{ Unstandardized Coefficients } & \multirow{2}{*}{$\begin{array}{c}\begin{array}{c}\text { Standardized } \\
\text { Coefficients }\end{array} \\
\text { Beta }\end{array}$} & \multirow{2}{*}{$t$} & \multirow{2}{*}{ Sig. } \\
\hline & & $\mathrm{B}$ & Std. Error & & & \\
\hline \multirow[t]{6}{*}{1} & (Constant) & 1.081 & .289 & & 3.741 & .001 \\
\hline & GPM & -.375 & .379 & -.193 & -.989 & .331 \\
\hline & ROE & -1.780 & 1.257 & -.276 & -1.416 & .167 \\
\hline & DER & .629 & .315 & .374 & 1.999 & .055 \\
\hline & DAR & .009 & .018 & .084 & .491 & .627 \\
\hline & Current Ratio & -.007 & .012 & -.098 & -.557 & .582 \\
\hline
\end{tabular}

\section{Basic of t-test decision making:}

1. If sig value $<0.1$ or $-t$ table $<t$ count $<t$ table, then variable $X$ has affected $Y$ variable obviously.

2. If sig value $>0.1$ or $-t$ count $<-t$ table or $t$ count $>t$ table, nevertheless $X$ variable has not affected $Y . T_{\text {table }}$ equation $=\mathrm{t}(\alpha / 2 ; n-k-1)=\mathrm{t}(0.05: 29)=1.699$.

a. $\operatorname{GPM}\left(\mathrm{X}_{1}\right)$ upon PBV $(\mathrm{Y})$

Test result of GPM $\left(\mathrm{X}_{1}\right)$ effect upon PBV $(\mathrm{Y})$ has identified sig value of GPM $\left(\mathrm{X}_{2}\right)$ effect upon PBV $(\mathrm{Y})$ is $0.331>0.1$ and $t$ count $-0.989>-1.699$, it can conclude that GPM variable is having a contribution to PBV. Negative value has indicated that GPM is having an inverted correlation with PBV. It can be concluded that GPM has negatively and significantly affected PBV.

b. $\operatorname{ROE}\left(\mathrm{X}_{2}\right)$ upon PBV $(\mathrm{Y})$

Test result of ROE $\left(\mathrm{X}_{2}\right)$ effect upon PBV $(\mathrm{Y})$ has indicated sig value of ROE $\left(\mathrm{X}_{2}\right)$ effect upon PBV $(\mathrm{Y})$ is $0.167>0.1$ and $t$ count $-1.416>-1.699$, and it can be concluded that ROE variable is having a contribution to PBV. Value of $t$ negative has indicated that ROE is having an inverted correlation with PBV. However, it is concluded that ROE has negatively and significantly affected PBV.

c. $\operatorname{DER}\left(\mathrm{X}_{3}\right)$ upon PBV $(\mathrm{Y})$

Test result of DER $\left(\mathrm{X}_{3}\right)$ effect upon PBV $(\mathrm{Y})$ has indicated sig.value of

Gilang Ramadhan Fajri: The Effect of Rentability Ratio, Solvability Ratio, Liquidity Ratio upon the Company's Value (Emperical Study of Mining companies Sub Sector of Metal and Other Mineral Registered in The Indonesia Stock Exchange in 2012 - 2016) 
DER $\left(\mathrm{X}_{3}\right)$ effect upon PBV $(\mathrm{Y})$ is $0.055<0.1$ and $t$ count of $1.999>1.699$, and it can be concluded that DER variable is not having a contribution to PBV. Vatlue of t positive has indicated that DER is having a correlation which is the same direction with PBV. It is concluded that DER has not significantly affected PBV.

d. $\operatorname{DAR}\left(\mathrm{X}_{4}\right)$ upon PBV $(\mathrm{Y})$

Test result of DAR $\left(X_{4}\right)$ effect upon PBV $(Y)$ has indicated that sig.value of DAR $\left(\mathrm{X}_{4}\right)$ effect upon PBV $(\mathrm{Y})$ is $0.627>0.1$ and $t$ count of 0.491 $<1.699$. it has concluded that DAR variable is having a contribution to PBV. Value of $t$ positive has indicated that DAR has correlated the same direction with PBV. It can be concluded that DAR has positively and significantly affected PBV.

e. Current Ratio $\left(\mathrm{X}_{5}\right)$ upon PBV $(\mathrm{Y})$

Test result of the effect of Current Ratio $\left(X_{5}\right)$ upon PBV $(Y)$ has indicated sig value of the effect of Current Ratio $\left(\mathrm{X}_{5}\right)$ upon PBV $(\mathrm{Y})$ is 0.582 $>0.1$ and t count of $-0.557>-1.699$ concluding that Current Ratio variable has contributed PBV. Value $t$ negative has indicated that Current Ratio is having an inverted correlation with PBV. Hence, it can be concluded that Current Ratio has negatively and significantly affected PBV.

\section{Simultaneous Hypothesis Test ( $F$ test)}

\begin{tabular}{|l|l|c|c|c|c|c|}
\multicolumn{2}{|c|}{ ANOVA $^{\text {a }}$} \\
\hline \multirow{2}{*}{1} & Model & $\begin{array}{c}\text { Sum of } \\
\text { Squares }\end{array}$ & df & Mean Square & F & Sig. \\
\hline & Regression & 8.753 & 5 & 1.751 & 2.392 & $.062^{\text {b }}$ \\
\cline { 2 - 8 } & Residual & 21.223 & 29 & .732 & & \\
\cline { 2 - 5 } & Total & 29.976 & 34 & & & \\
\hline
\end{tabular}

The calculation above has resulted $F$ count of 2.392 and $P$ value of 0.062 . It means that $P$ value is less than 0.1 and $f$ count of 2.392 is bigger than $F$ table of $2.049(\mathrm{~F}$ table $=\mathrm{F}(\mathrm{k} ; \mathrm{n}-\mathrm{k})$ so that it has concluded that the hypothesis is accepted which explains that the variables of GPM, ROE, DAR, DER and Current Ratio have simultaneously affected PBV.

J. Determinant Coefficient Test $\left.\mathbf{( R}^{2}\right)$

\begin{tabular}{|l|c|r|r|r|}
\multicolumn{5}{c|}{ Model Summary $^{\mathbf{b}}$} \\
\hline Model & $\mathrm{R}$ & R Square & $\begin{array}{c}\text { Adjusted R } \\
\text { Square }\end{array}$ & $\begin{array}{c}\text { Std. Error of the } \\
\text { Estimate }\end{array}$ \\
\hline 1 & $.540^{\mathrm{a}}$ & .292 & .170 & .85547 \\
\hline
\end{tabular}

Result of the analysis of multiple linear regression is indicated on the adjusted $R$ square of 0.17 identifying that Price Book Value (PBV) has been affected by GPM, ROE, DAR, DER and Current Ratio which is $17 \%$ and the remaining of $83 \%$ Price Book Value (PBV) at the mining companies, sub sector metal and other minteral registered in the Indonesia Stock Exchange for the period of 2012 - 2016 has been affected by other variables which is studied yet in this research.

\section{CONCLUSION AND SUGGESTIONS}

\section{A. Conclusion}

1. The effect of Rentability Ratio upon the value of the company has been measured by Gross Profit Margin and Return on Equity. The higher the rentability

Gilang Ramadhan Fajri: The Effect of Rentability Ratio, Solvability Ratio, Liquidity Ratio upon the Company's Value (Emperical Study of Mining companies Sub Sector of Metal and Other Mineral 
achieved by the company, the higher the value of the company would be, so that, in order to elevate the company's value, the company should have to improve its job performance by controlling cost of goods for sales and identifying the capacity the company to produce the products efficiently.

2. The effect of Solvability Ratio upon the value of the company has been measured by Debt to Equity Ratio and Debt to Asset Ratio which has been affecting the company having huge Solvability Ratio and high risk upon either long-term capital fundings or short-term one bigger than the company which is having low solvability level and low risk when the economics situation has been decreasing, however when the economic situation has been better, the opportunity to get the profit is low as well.

3. The Effect of Liquidity Ratio upon the company value has been measured by Current Ratio. The bigger the comparison between current assets and current liabilities has happened, the higher the capability of the company can cover its current liabilities. Big current ratio can identify surplus of cash flow has happened, it has explained either receivable big profit or the company has not invested the money effectively.

4. Based on the result of the research and the variables being used during the period of year, variable debt to asset (DAR) has dominantly been affecting the company value of 0.627 or $62.7 \%$. It has indicated the proportion of company's asset has been financed by liabilities instead of by the equity. This ratio is used to determine the financial risk of a business. The ratio which is bigger that $50 \%$ has indicated that mostly the assets have been financed by the liabilities, however, low ratio has indicated that mostly the assets has originately come from the equity.

\section{B. Suggestions}

Recommendation or suggestions provided for next research are as follows;

1. Adjusted $R$ square which is still small should have to be added by other variables which are probably affecting PBV for the purpose of next research, such as, Dividend Payout Ratio, Institutional ownership, managerial ownership and Activity Ratio.

2. This research has been studying only on the mining companies, sub-sector of other mineral and the observation has been done relatively in a short-term period which is for 5 years period only and limited samples. For further research, it could include more number of years of the research in order to get an accurate result and to enlarge the sample of the research.

\section{REFERENCES}

Agnes, Sawir. 2008. Analisis kinerja keuangan dan perencanaan keuangan. Jakarta: PT Gramedia Pustaka Utama.

Brealey, Richard A. Stewart C, Myers. Alan J, Marcus. 2001. Fundamentals of corporate finace. Third Edition. Singapore: Mc Graw-Hill.

Ghozali, I. 2013. Aplikasi analisis multifariate dengan program IBM SPSS 21. Edisi Ketujuh. Semarang: UNDIP.

Ista Yansi Rinnaya, Rita Andini, Abrar Oemar, 2016, pengaruh profitabilitas, rasio aktivitas, keputusan pendanaan keputusan investasi terhadap nilai perusahaan (studi empiris pada perusahaan manufaktur yang terdaftar di BEI tahun 20102014), Journal of Accounting, Volume 2 No. 22016.

Gilang Ramadhan Fajri: The Effect of Rentability Ratio, Solvability Ratio, Liquidity Ratio upon the Company's Value (Emperical Study of Mining companies Sub Sector of Metal and Other Mineral Registered in The Indonesia Stock Exchange in 2012 - 2016) 
The Accounting Journal of BINANIAGA Vol. 03, No. 01, June 2018

PISSN: $2527-4309$

EISSN: $2580-1481$

Margono. 2004. Metodologi penelitian pendidikan. Jakarta: PT. Rineka Cipta.

Priyatno, Duwi, 2014. Program IBM SPSS 22 pengolah data terpraktis. Yogyakarta: Penerbit Andi Yogyakarta

Riyanto, Bambang, 2008. Dasar-dasar pembelajaran perusahaan, BPFE,Yogyakarta.

Sawir, Agnes, 2009. Analisa kinerja keuangan dan perencanaan keauangan perusahaan, PT. Gramedia Pustaka Utama, Jakarta.

Sugiyono. 2010. Metode penelitian pendidikan pendekatan kuantitatif, kualitatif, dan R \& D. Bandung: Alfabeta

V. Wiratna Surjarweni, 2016. Kupas tuntas penelitian akuntansi dengan SPSS. Yogyakarta: Pustaka Baru Press.

Wahyono, Hadi, 2002. Komperasi kinerja perusahaan bank dan asuransi studi empiris di Bursa Efek Jakarta,

www.idx.co.id.

www.sahamok.com

Gilang Ramadhan Fajri: The Effect of Rentability Ratio, Solvability Ratio, Liquidity Ratio upon the Company's Value (Emperical Study of Mining companies Sub Sector of Metal and Other Mineral Page : 50 Registered in The Indonesia Stock Exchange in 2012 - 2016) 